\title{
Breast Milk Lipids and Fatty Acids in Regulating Neonatal Intestinal Development and Protecting against Intestinal Injury
}

\author{
David Ramiro-Cortijo ${ }^{1,+}{ }^{\circledR}$, Pratibha Singh ${ }^{1,+}\left(\mathbb{D}\right.$, Yan Liu ${ }^{1}$, Esli Medina-Morales ${ }^{1}{ }^{(}$,

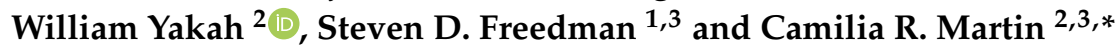 \\ 1 Division of Gastroenterology, Beth Israel Deaconess Medical Center, Harvard Medical School, \\ 330 Brookline Avenue, Boston, MA 02215, USA; dramiro@bidmc.harvard.edu (D.R.-C.); \\ psingh6@bidmc.harvard.edu (P.S.); yliu19@seas.harvard.edu (Y.L.); \\ jemedina@bidmc.harvard.edu (E.M.-M.); sfreedma@bidmc.harvard.edu (S.D.F.) \\ 2 Department of Neonatology, Beth Israel Deaconess Medical Center, Harvard Medical School, \\ 330 Brookline Avenue, Boston, MA 02215, USA; wyakah@bidmc.harvard.edu \\ 3 Division of Translational Research, Beth Israel Deaconess Medical Center, Harvard Medical School, \\ 330 Brookline Avenue, Boston, MA 02215, USA \\ * Correspondence: cmartin1@bidmc.harvard.edu \\ + These authors have equal contribution.
}

Received: 31 January 2020; Accepted: 16 February 2020; Published: 19 February 2020

\begin{abstract}
Human breast milk is the optimal source of nutrition for infant growth and development. Breast milk fats and their downstream derivatives of fatty acids and fatty acid-derived terminal mediators not only provide an energy source but also are important regulators of development, immune function, and metabolism. The composition of the lipids and fatty acids determines the nutritional and physicochemical properties of human milk fat. Essential fatty acids, including long-chain polyunsaturated fatty acids (LCPUFAs) and specialized pro-resolving mediators, are critical for growth, organogenesis, and regulation of inflammation. Combined data including in vitro, in vivo, and human cohort studies support the beneficial effects of human breast milk in intestinal development and in reducing the risk of intestinal injury. Human milk has been shown to reduce the occurrence of necrotizing enterocolitis (NEC), a common gastrointestinal disease in preterm infants. Preterm infants fed human breast milk are less likely to develop NEC compared to preterm infants receiving infant formula. Intestinal development and its physiological functions are highly adaptive to changes in nutritional status influencing the susceptibility towards intestinal injury in response to pathological challenges. In this review, we focus on lipids and fatty acids present in breast milk and their impact on neonatal gut development and the risk of disease.
\end{abstract}

Keywords: breast milk; milk fat globule; long chain polyunsaturated fatty acids; premature infants; necrotizing enterocolitis

\section{Introduction}

Human milk is a complex matrix of bioactive proteins, lipids, enzymes, hormones, and vitamins that collectively optimize infant development [1]. Understanding the lipid nutritional composition of breast milk provides guidance for defining adequate nutrient intake in critically ill infants, given that human breast milk fat provides almost 50\% of energy intake for neonates up to 6 months of age [2]. Multiple lipid classes and compounds also found in human milk have been associated with neonatal health outcomes [3], such as adequate growth, neurocognitive development and function, regulation of inflammation and infection risk, and reduced risk of later metabolic and cardiovascular disease in 
adulthood. Exposure to these compounds during infancy varies, however, as it is now well understood that human milk composition is highly variable between individuals with some key determinant factors being maternal health and dietary patterns [4]. In this review, we will discuss (1) lipid and fatty acid content in breast milk, and (2) how these compounds contribute to gut development and gut health.

\section{Lipids and Fatty Acid Composition in Human Breast Milk}

\subsection{Concentrations of Breast Milk Lipids and Fatty Acids}

Breast milk fat content increases with time or "maturation". In mothers of full-term infants, colostrum fat content is $2.2 \mathrm{~g} / 100 \mathrm{~mL}$, increasing to $3.0 \mathrm{~g} / 100 \mathrm{~mL}$ in transitional milk, and $3.4 \mathrm{~g} / 100 \mathrm{~mL}$ in mature milk [5]. In contrast, mothers with preterm neonates have higher breast milk fat concentrations [6] with values of 2.6, 3.6, and $3.9 \mathrm{~g} / 100 \mathrm{~mL}$ in colostrum, transitional, and mature milk, respectively [7]. Saturated fatty acid content in breast milk lipids represents $53.2 \%$ in colostrum, 62.1\% in transitional milk, and 58.0\% in mature milk [8,9]. Table 1 shows the relative contribution of principal saturated and monounsaturated fatty acids in breast milk. Palmitic acid (C16:0), a major saturated fatty acid, provides approximately $25 \%$ of all milk fatty acids [9]. The proportion of monounsaturated fatty acids is more stable than saturated fatty acids and make up about $45 \%-50 \%$ of breast milk during lactation [9]. Thirty-six percent of the monounsaturated fatty acids in breast milk is oleic acid (C18:1n-9) and provides an important function in reducing the melting point of triglycerides, thus providing the liquidity required for the formation, transport, and metabolism of the milk fat globule $[10,11]$. Long chain polyunsaturated fatty acids (LCPUFAs) represent about $15 \%$ of the total lipids in breast milk and have been extensively studied for their developmental, cardioprotective, anti-cancer, anti-inflammatory, and antioxidant biological functions [12,13].

Table 1. Fatty acid profile of breast milk across lactation stages.

\begin{tabular}{|c|c|c|c|c|c|c|}
\hline & \multicolumn{3}{|c|}{ Term Infants } & \multicolumn{3}{|c|}{ Preterm Infants } \\
\hline & Colostrum & Transitional & Mature & Colostrum & Transitional & Mature \\
\hline \multicolumn{7}{|c|}{ Saturated Fatty Acids } \\
\hline Caprylic acid (C8:0) & $0.07-0.19$ & $0.2-0.31$ & $0.2-0.3$ & $0.03-0.03$ & $0.09-0.11$ & $0.16-0.16$ \\
\hline Capric acid (C10:0) & $0.5-1.04$ & $1.2-1.6$ & $1.5-1.8$ & $0.09-0.09$ & $1.0-1.7$ & $1.2-2.1$ \\
\hline Lauric acid (C12:0) & $2.8-3.5$ & $5.4-6.6$ & $5.7-6.5$ & $3.2-4.6$ & $5.7-7.5$ & $5.7-8.1$ \\
\hline Myristic acid (C14:0) & $5.4-6.0$ & $6.6-7.5$ & $6.5-7.1$ & $5.8-7.2$ & $8.0-9.2$ & $7.4-9.0$ \\
\hline Palmitic acid (C16:0) & $24.3-25.5$ & $21.9-23.3$ & $21.7-22.7$ & $22.5-24.1$ & $21.5-23.5$ & $20.9-22.3$ \\
\hline Stearic acid (C18:0) & $6.2-6.6$ & $6.1-6.7$ & $6.3-6.6$ & $5.8-6.5$ & $6.0-6.9$ & $6.2-7.1$ \\
\hline Arachidic acid (C20:0) & $0.19-0.25$ & $0.20-0.32$ & $0.20-0.26$ & $0.16-0.18$ & $0.15-0.15$ & $0.20-0.30$ \\
\hline \multicolumn{7}{|c|}{ Monounsaturated Fatty Acids } \\
\hline Myristoleic acid (C14:1n-5) & $0.13-0.23$ & $0.19-0.25$ & $0.18-0.22$ & $0.11-0.13$ & $0.22-0.22$ & $0.21-0.21$ \\
\hline Palmitoleic acid (C16:1n-7) & $1.9-2.2$ & $2.0-2.4$ & $2.2-2.4$ & $1.7-1.8$ & $2.1-2.5$ & $2.0-2.5$ \\
\hline Oleic acid (C18:1n-9) & $34.7-35.9$ & $31.2-33.2$ & $32.2-33.6$ & $30.6-33.7$ & $30.5-34.3$ & $31.7-36.7$ \\
\hline Vaccenic acid (C18:1n-7) & $2.6-2.8$ & $1.9-2.0$ & $1.7-2.1$ & $2.3-2.4$ & $2.5-2.6$ & $2.1-2.2$ \\
\hline Erucic acid (C22:1n-9) & $0.20-0.24$ & $0.14-0.28$ & $0.10-0.12$ & $0.16-0.16$ & $0.10-0.14$ & $0.08-0.05$ \\
\hline \multicolumn{7}{|c|}{ n-3 Polyunsaturated fatty acids (n-3 LCPUFAs) } \\
\hline$\alpha$-Linolenic acid (C18:3n-3) & $0.74-0.90$ & $0.84-1.06$ & $0.91-1.03$ & $0.69-1.09$ & $0.70-1.02$ & $0.85-1.13$ \\
\hline Eicosapentaenoic acid (C20:5n-3) & $0.08-0.12$ & $0.11-0.17$ & $0.08-0.10$ & $0.06-0.10$ & $0.10-0.16$ & $0.08-0.16$ \\
\hline Clupanodonic acid (C22:5n-3) & $0.27-0.33$ & $0.19-0.25$ & $0.14-0.16$ & $0.30-0.34$ & $0.24-0.36$ & $0.16-0.24$ \\
\hline Docosahexaenoic acid (C22:6n-3) & $0.47-0.55$ & $0.40-0.52$ & $0.28-0.34$ & $0.43-0.71$ & $0.47-0.67$ & $0.31-0.49$ \\
\hline \multicolumn{7}{|c|}{ n-6 Polyunsaturated fatty acids (n-6 LCPUFAs) } \\
\hline Linoleic acid (C18:2n-6) & $13.5-15.3$ & $13.4-14.8$ & $14.3-15.7$ & $13.7-16.3$ & $11.4-13.6$ & $12.3-14.4$ \\
\hline$\gamma$-Linolenic acid (C18:3n-6) & $0.07-0.11$ & $0.10-0.18$ & $0.14-0.20$ & $0.07-0.07$ & $0.09-0.13$ & $0.11-0.21$ \\
\hline Eicosadienoic acid (C20:2n-6) & $0.82-0.96$ & $0.53-0.63$ & $0.35-0.41$ & $0.89-0.95$ & $0.28-0.30$ & $0.24-0.24$ \\
\hline Dihomo- $\gamma$-Linolenic acid (C20:3n-6) & $0.56-0.64$ & $0.46-0.52$ & $0.39-0.43$ & $0.69-0.81$ & $0.47-0.55$ & $0.40-0.50$ \\
\hline Arachidonic acid (C20:4n-6) & $0.73-0.81$ & $0.61-0.69$ & $0.45-0.51$ & $0.68-0.90$ & $0.54-0.68$ & $0.48-0.58$ \\
\hline Docosatetraenoic acid (C22:4n-6) & $0.29-0.39$ & $0.19-0.25$ & $0.09-0.11$ & $0.44-0.49$ & $0.22-0.22$ & $0.13-0.17$ \\
\hline Adrenic acid (C22:5n-6) & $0.13-0.21$ & $0.09-0.13$ & $0.06-0.10$ & $0.15-0.17$ & $0.05-0.05$ & $0.05-0.09$ \\
\hline
\end{tabular}

Data shows the relative proportion in total lipids (\%) between mothers who had term and preterm infants. Colostrum = 0-5 days of postnatal life (DPL); Transitional = 6-15 DPL; Mature = 16-60 DPL. Data abstracted from [6]. 


\subsection{Breast Milk Fat Globules}

Lipids in breast milk are present in the form of milk fat globules homogenously distributed within the aqueous phase of milk. The average size of milk fat globules, depending on the stage of lactation, varies between 0.1 and $15 \mu \mathrm{m}$. Breast milk fat globules are larger during the $24 \mathrm{~h}$ postpartum and the size reduces to similar sizes in transitional and mature milk [14,15]. Fat globules possess a core-shell structure, as illustrated in Figure 1. The membranes of a fat globule are composed of a unique tri-layer structure. The formation of a fat globule follows a coordinated sequence of synthesis and secretion. Briefly, the triglyceride core is first synthesized at the endoplasmic reticulum, and the first closely packed single layer is formed during secretion into the cytoplasm. The second, outer phospholipid bilayer is formed during secretion from the epithelial cell of the lactocyte [16,17]. These layers, also known as milk fat globule membranes (MFGM), are $8-10 \mathrm{~nm}$ thick and contains $70 \%$ protein, $25 \%$ phospholipid, and 5\% cerebrosides/cholesterol. The phospholipid composition is distinctive between the layers, the major phospholipid components are phosphatidylethanolamine $(30 \%)$ in the single layer, and phosphatidylcholine (35\%) and sphingomyelin (25\%) in the double layer. The MFGM also contains important proteins such as mucin-1, butyrophilin, xanthine oxidoreductase, glycoprotein bovine lactadherin $6 / 7$, selectively placed in the double layer, which are important in infant health and have been discussed comprehensively in another review [18-20].

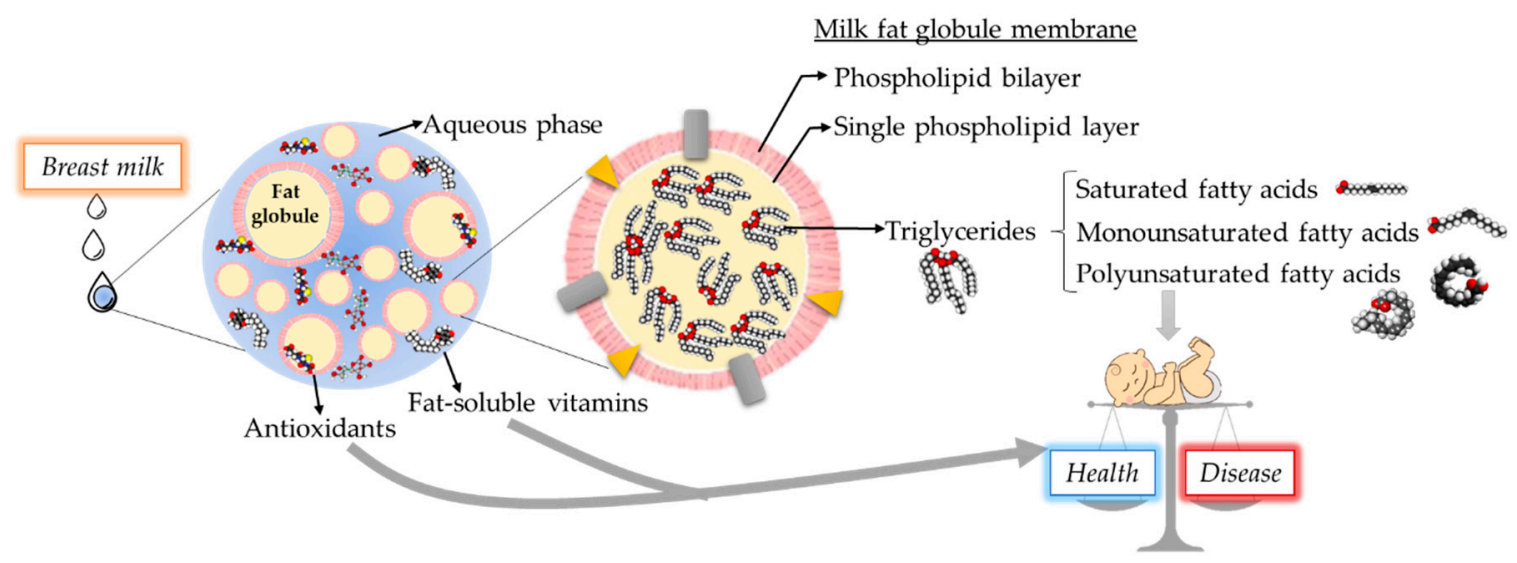

Figure 1. Breast milk fat components and relationship with neonatal health-disease balance. Scheme of fat globule illustrating of the core-shell structure.

Bovine milk based infant formulas have attempted to closely mimic the lipid composition of naturally originated breast milk. However, large differences still exist in physiochemical properties between the fat globule in breast milk and the fat globule found in formula. Fat globules in conventional infant formulas are smaller $(0.1-1.0 \mu \mathrm{m})$ in milk protein (caseins and whey proteins), dominated membranes induced by the manufacturing process of centrifugation, homogenization, and heat treatment [21-23]. Adding bovine milk phospholipids to an amount of $1.5 \%$ of total fat with modified processing procedures have shown to yield infant formulas with larger fat globules $[23,24]$. In addition, in human milk sphingomyelin is the dominant phospholipid versus phosphatidylcholine and phosphatidylethanolamine in formula [18,23]. While researchers are still making efforts to understand the functionalities of MFGM, there are already commercialized products supplementing MFGMs from bovine milk cream. The effectiveness of supplementation of MFGM in formula has been demonstrated in several independent cellular and animal studies, and clinical trials [25-28]. In mouse and rat studies, bovine MFGMs showed cognitive and neuronal development improvement and this observation was further illustrated in multiple clinical trials, suggesting bovine MFGMs have positive effects on cognitive development and protection against bacterial infection.

The downstream physiochemical properties of milk fat globules are dependent on the efficiency of fat digestion in infants. The interfacial structure, which is represented by the distribution of complex 
lipids in the MFGM, and the available fat area, defined as the globule size, are of primary importance for adequate lipolysis and digestion in the neonate [21,29]. In preterm infants, human milk fat globules were digested faster than preterm formulas in a digestive time range of 10 to $50 \mathrm{~min}$ [30]. It has been postulated that the difference in the digestion rate is caused by the variation of fat globule size and membrane composition in human milk versus preterm formulas [22]. Research in the MFGM field continues to garner interest as data indicate that breast milk fat globules could provide the right vehicle for bioactive factors, such as vitamin $\mathrm{E}$ and digestive enzymes, to be effectively delivered optimizing bioavailability. The MFGM fraction may have important biological roles for the development of physiological neonatal systems and immune function [9].

\subsection{Complex Lipids in Breast Milk}

Although about $98 \%-99 \%$ of lipids found in breast milk are in the form of triglycerides, other complex lipid types such as glycerophospholipids (e.g., phosphatidylethanolamine, phosphatidylcholine) and sphingolipids account for $0.2 \%-1.0 \%$, or $100-400 \mathrm{mg} / \mathrm{l}$ of breast milk lipids [31]. These lipids are mostly located in MFGMs and extracellular vesicles such as exosomes in breast milk. Sphingolipids share a similar sphingosine backbone, but the type of headgroup attached determines the type of sphingolipid (sphingomyelin, glucosyl and lactosylceramides, or gangliosides). Quantification of complex lipids in human milk shows that sphingomyelin is the most abundant, making up about $36 \%$ of complex lipids, followed by glycerophospholipids, phosphatidylethanolamine $(29 \%)$, and phosphatidylcholine $(25 \%)$ [23,32,33]. Exosomes are also enriched with sphingolipids, particularly ceramide and sphingomyelin, and glycerophospholipids such as phosphatidylserine [34]. Like fatty acid levels, the composition of sphingolipids in breast milk can also be modified by diet. Lopez et al. demonstrated an increase in phospholipid and sphingolipid content in MFGM from cows fed with diets rich in LCPUFAs [35].

\section{Breast Milk Lipids Enhance Neonatal Intestinal Development and Protect against Injury}

The impact of lipids and fatty acids on gut development is not as well studied as in other organ systems. To date, the contribution of lipids and essential fatty acids on early postnatal gut development and subsequent host responses after an inciting event remain unknown. Understanding the changes in intestinal development in response to early priming with varying lipids and fatty acids during a pre-injurious state will be helpful to investigate the underlying mechanisms by which fatty acids may modulate the risk of intestinal injury and inflammation.

\subsection{Saturated and Monounsaturated Fatty Acids}

Role in intestinal development and injury. Dietary saturated and monounsaturated fatty acids have been shown to influence the microbiota diversity of human breast milk and neonatal gut [36]. Breast milk fatty acid composition changes rapidly in response to fat intake in the maternal diet. Higher levels of monounsaturated fatty acids in breast milk resulted in a decrease of Staphylococcus, Pseudomonas, Lactobacillus, and Bifidobacterium, while the level of saturated fatty acids in breast milk was negatively correlated with Streptococcus. The fatty acid composition of human milk along with specific microbial constitution likely affect the developmental programming of immune ontogeny in infants. Bifidobacterium and Lactobacillus spp. are crucial for immunological functions and mucosal barrier homeostasis, including tolerance, mucus production, tight junction expression, and T-helper cell balance [37].

In human breast milk triglycerides, the sn-2 position is commonly occupied by palmitic acid. In contrast, in palm-oil based human infant formula, palmitic acid is mainly present at the sn- 1 or sn-3 position. The difference in sn- position leads to impaired absorption of calcium and fat, which negatively influence early bone accretion [38]. When human infant formula contains palmitic acid at the sn-2 position, improved absorption of fat and calcium with absorption rates similar to those seen in breastmilk-fed infants is observed [39]. Consequently, a low palmitic acid formula has been developed 
to reduce the amount of sn-1, 3 palmitic acids thus enabling higher absorption of calcium and fat in neonates $[40,41]$.

Palmitic acid at the sn-2 position of the triacylglycerol backbone imparts benefits for neonatal intestinal and immunological health outcomes [42]. Lu et al. examined the effect of diet with sn-2 palmitic acids using Muc2 deficient mice, an animal model for spontaneous enterocolitis. Compared to sn-1,3 palmitic acids of triglycerides, sn-2 palmitic acids resulted in decreased intestinal injury and inflammation by upregulation of PPAR- $\gamma$, antioxidant enzymes (superoxide dismutase, glutathione peroxidase), and induction of an immunosuppressive T-regulatory cell response [43]. These data support the role of the saturated fatty acid, palmitic acid, specifically in sn-2 configuration, as being important for intestinal mucosal homeostasis, gut microbiome, and immune response [44]. However, the lack of evidence in clinical trials to establish a cause and effect relationship between the palmitic acid at sn-2 position and neonatal health outcomes, led the European Society for Paediatric Gastroenterology, Hepatology, and Nutrition to recommend that the inclusion of high sn-2 palmitic acid cannot be considered essential in human infant formula [45,46].

Among monounsaturated fatty acids, oleic acid has been shown to possess an immunomodulatory function. However, the role of oleic acid in immune responses is still controversial. An olive oil-based diet in adult mice showed improved immune responses against bacterial infection with enhanced phagocytic activity by macrophages $[47,48]$. In vitro, human lymphocytes treated with oleic acid resulted in increased neutral lipid accumulation thought to protect against lipid toxicity [49]. However, these studies also demonstrated oleic acid-induced cell death and necrosis mediated by caspase- 3 activation. The role of oleic acid remains largely unexplored in infants [49].

\subsection{Polyunsaturated Fatty Acids}

Role in intestinal development. It is well-documented that in the early postnatal period of preterm infants, whole blood docosahexaenoic acid (DHA, C22:6n-3) and arachidonic acid (ARA, C20:4n-6) deficits and linoleic acid (LA, C18:2n-6) excesses occur within the first postnatal week [50]. Although these altered fatty acid profiles have been linked to the increased risk of developing bronchopulmonary dysplasia, retinopathy of prematurity, and late onset sepsis, the impact of these altered fatty acid profiles on intestinal development has just recently been described [50-52].

Singh et al. took advantage of the fat- 1 transgenic mouse model to examine the differences in postnatal gut development in mouse pups in control, wild-type dam fed mice versus dam fed fat-1 transgenic mice [52]. Relative to the wild-type group, fat-1 mice had a greater $n-3$ shift in their intestinal fatty acid levels with an increase in DHA and eicosapentaenoic acid (EPA, C20:5n-3), and a decrease in ARA in the pre-weaning period. Of clinical importance is the parallel of the wild-type fatty acid levels with systemic levels observed in the postnatal period of preterm infants and the parallel of fat-1 fatty acid levels to systemic levels observed in preterm infants supplemented with enteral or parenteral fish oil [53]. This study confirmed that fatty acid exposure and intestinal levels do impact postnatal intestinal development and that a balance between both n- 3 and n- 6 may be critical in this early developmental period. In the pre-weaning period, while an n-3 dominant pattern increased gene expression of cell differentiation markers (EphB2, Fzd5) and fatty acid metabolism (fatty acid binding protein 2 and 6), this n-3 dominant pattern also decreased villus height over time and reduced expression of markers that inform innate host defenses, such as a reduced number of acidic mucin filled goblet cells, reduced expression of tight-junction genes (claudin 3 and 7), and reduced gene expression of muc2, trefoil factor 3, toll like receptor 9, and cathelicidin antimicrobial peptide [52]. These data suggest that that LCPUFA changes reflective of those seen in neonatal intensive care units likely influence the trajectory of postnatal intestinal development.

In a preterm piglet model evaluating the effect of an enteral complex lipid emulsion containing LCPUFAs on early postnatal fatty acid levels, it was demonstrated that an ARA:DHA ratio $>1.0$ compared to a ratio $<1.0$ uniquely prevented the postnatal deficit of ARA while also demonstrating increased ileal villus height and muscular thickness compared to the control soybean-oil and ARA:DHA 
$<1.0$ groups [54]. In contrast, parenteral nutrition did not show an effect on intestinal morphology and function in preterm piglet models, suggesting postnatal intestinal adaptation is driven more by enterally administered fatty acids versus parenteral delivery [55]. Wang et al. showed that both triglyceride (fish oil, DHA, and EPA) and phospholipid-derived n-3 LCPUFAs (DHA and EPA) enriched diets led to improved small intestine villus to crypt depth ratio in 4-week old mice. The villus to crypt depth ratio was significantly increased in the LCPUFA supplemented group compared to the control group, and this increase was more pronounced in the phospholipid-derived n-3 LCPUFAs compared to the triglyceride-derived n-3 group. Moreover, higher enrichment of gut- microbiota was observed in response to phospholipid-derived n-3 LCPUFAs [56].

Role in intestinal injury. Potential benefits of LCPUFAs have been reported in inflammatory bowel disease, a disease with similar pathology as necrotizing enterocolitis (NEC) [57,58]. However, human studies investigating the role of n-3 fatty acids in the prevention, treatment, and maintenance of remission inflammatory bowel disease have shown mixed results [59-65].

In vitro studies have consistently demonstrated anti-inflammatory actions of LCPUFAs. ARA and DHA treatment to intestinal epithelial cells blocked platelet-activating factor-induced toll like receptor 4 (TLR4) and platelet-activating factor receptor expression in intestinal epithelial cells [66]. Similarly, LCPUFA treated human fetal and adult intestinal epithelial cells demonstrated that DHA and ARA treatment led to a decreased IL-1 $\beta$-induced pro-inflammatory response [67]. The protective effect of LCPUFAs in intestinal inflammatory disease could be partly explained by their effect on gut barrier function [68]. Although in vitro studies have shown mixed results about the impact of LCPUFAs on intestinal permeability [52,69,70], LCPUFA treatment to human intestinal epithelial cells resulted in improved intestinal barrier by decreasing the impairment in intestinal permeability induced by cytokines [71,72].

In vivo studies support the role of LCPUFAs in reducing inflammation and modulating the risk for NEC. Studies evaluating the effect of n-3 fatty acids and their derivatives in adult mice and a rat model of colitis showed beneficial effects by reducing the expression of inflammatory mediators [73-78]. Furthermore, Gobbetti et al. showed the protective effect of n-6, but not n-3 LCPUFA containing diet on ischemia/perfusion induced intestinal injury in an adult murine model. Three-week-old mice supplemented with n-6 enriched diet for 9 weeks showed reduced intestinal damage and inflammation and this effect was mediated by increased level of lipoxin A4, suggesting the anti-inflammatory role of lipoxin A4 in ischemia/perfusion induced intestinal injury [79]. These results suggest that ARA is not only a precursor of pro-inflammatory lipid mediators but also plays a critical role in generating anti-inflammatory lipid mediators [80]. Altogether, the balance of n-3 and n-6 LCPUFAs plays a critical role in regulating intestinal pathophysiology and inflammation.

Several animal studies using experimental models of NEC have shown that LCPUFA supplementation results in reduced NEC incidence and its severity by regulating multiple pathways associated with intestinal inflammation/injury and necrosis, including TLR4, platelet-activating factor, and nuclear factor- $\mathrm{B}$ [81-83]. Preterm rats born to dams who were fed a DHA or EPA enriched diet and subjected to an NEC induction protocol showed significant decreased NEC-like colitis incidence [84]. In a different study, LCPUFA supplementation significantly reduced the incidence of NEC in a neonatal rat model compared with controls by downregulating phospholipase A(2)-II and platelet-activating factor receptor at 24 and $48 \mathrm{~h}$, respectively [81]. Compared to a control formula, three different LCPUFA supplementation strategies (ARA and DHA, egg phospholipid, DHA) showed reduced NEC incidence in a neonatal rat model of NEC by downregulating TLR4 expression [66]. Similarly, young mice supplemented with 10\% fish oil for 4 weeks showed protective effects against hypoxia-induced NEC with a reduction in platelet-activating factor as well as leukotriene B4 [85].

Several clinical trials have evaluated the impact of LCPUFAs in term and preterm infants. However, the data about the role of LCPUFAs in NEC is limited. Furthermore, in many of these studies, the assessment of the risk of NEC with nutritional intervention was a secondary outcome analysis. Differences in LCPUFA formulation, dosing, and study populations results in inconclusive data about 
the use of LCPUFA in the prevention of NEC. Despite promising results of LCPUFAs in experimental NEC in animal models, results in preterm human infants are mixed and limited.

A summary of LCPUFA supplemented feedings and NEC risk in preterm infants is shown in Table 2. The systemic review by Smithers et al. did not find any benefit of n-3 LCPUFA supplemented formula in the risk of NEC. In this work, the studies were not limited to preterm infants who are at the highest risk of developing NEC [86]. Fewtrell et al. included infants who received human milk, which could be a confounding factor in this study [87]. In the Carlson et al. study, no infant received human milk and the preterm infants were randomly assigned into two groups receiving either experimental formula containing egg phospholipids $(0.13 \%$ DHA and $0.41 \%$ ARA) or control group. The egg phospholipid-containing formula resulted in a significant decrease in NEC incidence compared to the control formula [88]. Currently, this is the only single-center human study demonstrated to decrease NEC incidence in response to LCPUFA supplementation. It is important to note that none of the trials looked at NEC incidence as a primary outcome. In addition, what is unclear is whether a potential benefit would be seen in a population of largely human milk fed infants, which is the current standard.

Table 2. Human studies of long-chain polyunsaturated fatty acid (LCPUFA) supplementation in preterm infants and necrotizing enterocolitis (NEC) risk.

\begin{tabular}{|c|c|c|c|c|c|}
\hline Reference & Study Design & Population & $\mathbf{n}$ & $\begin{array}{c}\text { Powerful and } \\
\text { Prevalence of NEC }\end{array}$ & $\begin{array}{l}\text { Principal Finding } \\
\text { in NEC }\end{array}$ \\
\hline $\begin{array}{l}\text { Smithers et al. } \\
\text { (2008) [86] }\end{array}$ & Systematic review & $<37$ GA & 1333 & $R R=[0.62-2.04]$ & $\begin{array}{l}\text { No benefit of } n-3 \\
\text { LCPUFA } \\
\text { supplemented } \\
\text { formula }\end{array}$ \\
\hline $\begin{array}{l}\text { Zhang et al. } \\
\text { (2014) [89] }\end{array}$ & Systemic review & $<32 \mathrm{GA}$ & 900 & $\mathrm{RR}=[0.23-1.10]$ & $\begin{array}{l}\text { No benfit of } \mathrm{n}-3 \\
\text { LCPUFA } \\
\text { supplementation }\end{array}$ \\
\hline \multicolumn{6}{|c|}{ Double-blinded randomized clinical trials } \\
\hline $\begin{array}{l}\text { Carlson et al. } \\
\text { (1998) [88] }\end{array}$ & $\begin{array}{c}\text { Formula supplemented with } \\
0.41 \% \text { ARA }+0.13 \% \text { DHA }\end{array}$ & $\begin{array}{c}<32 \mathrm{GA} \\
\text { BW between } \\
725-1375 \mathrm{~g}\end{array}$ & 119 & $\begin{array}{c}\text { Control }=17.6 \% \\
\text { Experimental }=2.9 \%\end{array}$ & $\begin{array}{l}\text { Significantly } \\
\text { decreased }\end{array}$ \\
\hline $\begin{array}{l}\text { Fewtrell et al. } \\
\text { (2002) [90] }\end{array}$ & $\begin{array}{c}\text { Formula supplemented with } \\
0.31 \% \text { ARA + } 0.17 \% \text { DHA } \\
\text { BM supplemented }\end{array}$ & $\begin{array}{c}<37 \mathrm{GA} \\
\mathrm{BW}<1750 \mathrm{~g}\end{array}$ & 197 & $\begin{array}{c}\text { Control }=11 \% \\
\text { Experimental }=19 \%\end{array}$ & $\begin{array}{l}\text { No significant } \\
\text { difference }\end{array}$ \\
\hline $\begin{array}{l}\text { Innis et al. } \\
(2002)[91]\end{array}$ & $\begin{array}{c}\text { with DHA } \\
\text { BM supplemented with } \\
\text { ARA + DHA }\end{array}$ & $\begin{array}{l}\text { BW between } \\
846-1560 \mathrm{~g}\end{array}$ & 194 & $\begin{array}{c}\text { Control }=1.6 \% \\
\text { Experimental }=1.5 \%\end{array}$ & $\begin{array}{l}\text { No significant } \\
\text { difference }\end{array}$ \\
\hline $\begin{array}{l}\text { Fewtrell et al. } \\
\text { (2004) [87] }\end{array}$ & $\begin{array}{c}\text { Formula supplemented with } \\
0.31 \% \text { ARA }+0.17 \% \text { DHA }\end{array}$ & $\begin{array}{c}<35 \mathrm{GA} \\
\mathrm{BW} \leq 2000 \mathrm{~g}\end{array}$ & 238 & $\begin{array}{c}\text { Control }=2 \% \\
\text { Experimental }=4 \%\end{array}$ & $\begin{array}{l}\text { No significant } \\
\text { difference }\end{array}$ \\
\hline $\begin{array}{l}\text { Clandinin et al. } \\
\text { (2005) [92] }\end{array}$ & $\begin{array}{c}\text { Formula supplemented with } \\
\text { DHA + ARA }\end{array}$ & $<35$ GA & 361 & $\begin{array}{c}\text { Control }=3 \% \\
\text { Experimental }=5 \%\end{array}$ & $\begin{array}{l}\text { No significant } \\
\text { difference }\end{array}$ \\
\hline $\begin{array}{l}\text { Henriksen et al. } \\
\text { (2008) [93] }\end{array}$ & $\begin{array}{l}\text { BM supplemented with } \\
6.7 \% \text { ARA + } 6.9 \% \text { DHA }\end{array}$ & $\mathrm{BW}<1500 \mathrm{~g}$ & 141 & $\begin{array}{c}\text { Control }=3 \% \\
\text { Experimental }=1.5 \%\end{array}$ & $\begin{array}{l}\text { No significant } \\
\text { difference }\end{array}$ \\
\hline $\begin{array}{l}\text { Makrides et al. } \\
\text { (2009) [94] }\end{array}$ & $\begin{array}{l}\text { High DHA }(1 \%) \\
\text { Low DHA }(0.3 \%)\end{array}$ & $<33 \mathrm{GA}$ & 657 & Adj. OR = [0.87-5.22] & $\begin{array}{l}\text { No significant } \\
\text { difference }\end{array}$ \\
\hline $\begin{array}{l}\text { Collins et al. } \\
\text { (2016) [95] }\end{array}$ & $\begin{array}{l}\text { Formula supplemented with } \\
\text { different doses of DHA }\end{array}$ & $<30 \mathrm{GA}$ & 53 & $\begin{array}{c}\text { Control }=9 \% \\
\text { Experimental }=9 \%\end{array}$ & $\begin{array}{l}\text { No significant } \\
\text { difference }\end{array}$ \\
\hline $\begin{array}{l}\text { Collins et al. } \\
\text { (2017) [96] }\end{array}$ & $\begin{array}{l}\text { BM supplemented with } \\
60 \mathrm{mg} / \mathrm{kg} / \text { day DHA }\end{array}$ & $<29$ WGA & 1273 & Adj. OR = [0.79-1.69] & $\begin{array}{l}\text { No significant } \\
\text { difference }\end{array}$ \\
\hline
\end{tabular}

\subsection{Milk Fat Globule Membranes}

Role in intestinal development. MFGM proteins have been identified [18] that exert multiple biological functions critical for intestinal development and health. Mucin 1 interacts with molecule-3-grabbing non-integrin, expressed by dendritic cells, in the infant gastrointestinal tract and subsequently inhibits binding of certain intestinal pathogenic bacteria to dendritic cells [97]. Moreover, mucin 1 demonstrates anti-viral properties against rotavirus infection [98]. Xanthine oxidoreductase, a predominant protein of MFGM, possesses antimicrobial activity and has been shown to inhibit the growth of Escherichia coli and Salmonella enteritides by generating superoxide and peroxide, thus providing 
protection to the neonatal gut [99]. Lactadherin, also known as milk fat globule-EGF factor 8, aids in the clearance of dead cells by macrophages through phagocytosis [100]. Exogenous administration of lactadherin decreased the inflammatory response and injury by enhancing phagocytosis of apoptotic cells in experimental sepsis and ischemia/perfusion injury models [101-103]. Furthermore, lactadherin deficient mice showed more severe injury in response to dextran sulfate sodium, which induces colitis, and the administration of human lactadherin attenuated the dextran sulfate sodium injury [104]. Results from in vitro and in vivo studies showed that lactadherin deficiency results in delayed epithelial cell renewal and turnover [105]. Together, these results suggest the importance of lactadherin in intestinal homeostasis and imply that the provision of lactadherin in human or bovine milk could be beneficial against intestinal injury/inflammation. Butyrophilin, another quantitatively major protein in human MFGM, has been considered as a potentially important regulator for immune function. In addition to its effect on the secretion of milk fat globules [106], butyrophilin induces apoptosis and promotes $\mathrm{T}$ cell response [107]. Finally, in rat pups, the addition of MFGM to formula resulted in an enteric microbiome and intestinal development pattern (measured by villus height, crypt depth, crypt cell proliferation, paneth and goblet cell counts, and tight junction proteins) more similar to breastfed rats compared to rats fed with formula without MFGM [108]. Collectively, these results suggest the important role of MFGM and MFGM proteins in shaping the gastrointestinal tract immune system and maintaining immune homeostasis.

Role in intestinal injury. MFGM supplemented formula in rat pups protects against $C$. difficile toxin [108] and LPS-induced intestinal inflammation [109]. In the latter study, MFGM supplementation protected against histological changes in the intestine, reduced inflammatory cytokines, and increased tight junction proteins. In an asphyxia, cold stress model of NEC in neonatal rat pups, MFGM supplementation reduced NEC incidence and severity with a concurrent reduction in TLR4 expression [110]. Clinical trials of MFGM supplementation have not been conducted in preterm infants. In 6-12-month-old infants supplemented daily with MFGM, the number of bloody diarrheal episodes was reduced significantly by almost 50\% [111]. Rapidly evolving and emerging evidence from animal model studies and clinical trials indicates the potential of beneficial effects of the combination of bioactive compounds or any specific component of MFGM to optimize postnatal intestinal development in the preterm infant and to protect against disease.

\subsection{Complex Lipids}

Role in intestinal development and injury. Breast milk provides complex lipids through the delivery of MFGMs and exosomes. Published data support the role of extracellular vesicles on intestinal development and protection from intestinal injury such as NEC [112-114]. When evaluated in totality versus in individual components, human milk-derived exosomes attenuate oxidative stress-induced cell death in intestinal epithelial cells [115] and enhance proliferation and migration of intestinal epithelial cells in preterm infants compared to those with full term birth [116].

Breast milk sphingolipids, such as sphingomyelin and gangliosides, are important modulators of neonatal intestinal development, the establishment of the gut microbiome, and inflammation [117]. Sphingomyelin is digested by nucleotide phosphodiesterase pyrophosphatase 7 (NPP7), a brush border enzyme of the intestinal epithelium, and generates ceramide, sphingosine, and sphingosine-1phosphate $[118,119]$. In contrast to sphingomyelin and ceramide, sphingosine is rapidly absorbed and largely converted to palmitic acid in the mucosa [120]. NPP7 is specifically expressed in intestinal mucosa and is highly expressed in the middle part of the jejunum and the lower colon.

NPP7 possesses phospholipase $C$ activity against platelet activating factor, a pro-inflammatory lipid mediator produced by gut epithelial cells [121]. Higher levels of platelet activating factor have been shown in inflammatory bowel disease, ischemic colitis and NEC [118]. Intrarectal administration of recombinant NPP7 significantly reduced the intestinal injury and inflammation against colitis in an adult rat model [122]. It is possible that NPP7 expression is dependent on gestational age or the changes in enzymatic activity that occur later after birth, which may predispose the preterm infant 
to intestinal injury. However, similar expression of NPP7 was observed in the meconium of term and preterm infants [123]. The anti-inflammatory benefits of sphingomyelin might be mediated through the induced changes in the microbiome. In an adult murine model, a diet containing $0.25 \%$ (wt/wt) milk sphingomyelin had lower fecal Gram-negative bacteria and higher fecal Bifidobacterium compared to mice fed with a high fat diet, and these changes were accompanied by reduced serum lipopolysaccharide levels in the sphingomyelin group [124].

Gangliosides have been reported to reduce pro-inflammatory signaling in the intestine [125] and protect the bowel in an infant model of necrotizing enterocolitis [126]. Weaning rats fed with ganglioside-enriched diets demonstrated increased ganglioside levels in the intestinal brush border and reduced levels of the pro-inflammatory mediator platelet activating factor [127]. In a follow-up study, rats fed with dietary gangliosides compared to controls exhibited reduced expression of pro-inflammatory mediators such prostaglandin E2, LTB4, IL-1 $\beta$, TNF- $\alpha$ in the intestinal mucosa following lipopolysaccharide-induced inflammation [128]. Similar to sphingomyelin, some of this mediation may be due to induced microbiome changes in the gut. In preterm infants, fecal Escherichia coli counts were lower and Bifidobacterial counts were higher in infants fed with a ganglioside-supplemented diet compared to infants fed a control milk formula [129].

Together, these studies support the role of sphingolipids, particularly sphingomyelin and gangliosides, as important mediators of intestinal development and protection against intestinal injury.

\section{Scientific Gaps and Future Directions}

Dietary lipids and fatty acids are of critical importance in several developmental processes such as immune responses, organogenesis, and central nervous system development. Although after a term pregnancy adipose stores and human milk continue to supply the infant with critical lipids and fatty acids, preterm infants do not have these sustainable sources with a lack of adipose tissue and minimal enteral feeding volumes. To prevent postnatal deficits of these critical nutrients, the preterm infant will likely require additional dietary supplementation. The specific content of such supplementation and the chemical composition to ensure adequate absorption remains to be defined. Based on the available data, infant formula should provide both ARA and DHA, and in an ARA:DHA ratio $>1$. Providing solely DHA or DHA exceeding ARA may induce undesirable health outcomes in infants, leading to adverse effects on growth and immune development $[130,131]$.

The precise mechanisms by which lipids and fatty acids mediate their effects on the developing intestine still need to be fully characterized. It is possible that dietary intervention may have different effects across different exposure times and different clinical contexts (during acute illness versus convalescence). As a result, studies that examine timing, composition, and dosing, including desirable target levels, are needed.

The role of human milk-derived vesicles, including the human milk fat globule and exosomes, may reveal an opportunity to present multiple critical molecules simultaneously and ensuring delivery and bioavailability to the intended site.

The biggest challenge in translational research is reconciling the disparate results obtained from animal models versus human clinical trials. Establishing animal models that better reflect the preterm neonatal experience, as well as refinement of humanoid model systems, will be essential in bridging the gap from bench to bedside.

\section{Conclusions}

The lipid and fatty acid content in human milk inform investigators and clinicians of the important nutrient pathways that facilitate growth, development, and resistance to disease. The preterm infant is uniquely vulnerable to nutrient deprivation, and parenteral and enteral feedings alone may not be sufficient to close the nutrient gaps that develop early after delivery. The science of breast milk will likely open new avenues of therapeutic options to minimize the health consequences of such nutrient 
gaps. An improvement in the experimental model systems will iteratively close the gap in translation from bench to bedside.

Author Contributions: Conceptualization and validation, S.D.F. and C.R.M.; investigation, resources and writing-original draft preparation, D.R.-C., P.S., Y.L., E.M.-M. and W.Y.; writing-review and editing, D.R.-C., S.D.F. and C.R.M.; supervision, C.R.M.; funding acquisition, C.R.M. All authors have read and agreed to the published version of the manuscript.

Funding: This research was funded by Charles $\mathrm{H}$ and Judy Hood Family Infant Health Research Program and National Institute of Diabetes and Digestive and Kidney Diseases (NIH R01 DK104346).

Conflicts of Interest: Martin and Freedman have grant support from Alcresta Therapeutics, Inc., and serve on the scientific advisory board of Prolacta Biosciences. Martin has grant support from Feihe International and Mead Johnson Nutrition; and serves on the scientific advisory boards of Fresenius Kabi and LUCA Biologics. The funders had no role in the writing of the manuscript, or in the decision to publish the results.

\section{References}

1. Gila-Diaz, A.; Arribas, S.M.; Algara, A.; Martin-Cabrejas, M.A.; Lopez de Pablo, A.L.; Saenz de Pipaon, M.; Ramiro-Cortijo, D. A review of bioactive factors in human breastmilk: A focus on prematurity. Nutrients 2019, 11, 1307. [CrossRef] [PubMed]

2. Grote, V.; Verduci, E.; Scaglioni, S.; Vecchi, F.; Contarini, G.; Giovannini, M.; Koletzko, B.; Agostoni, C.; European Childhood Obesity, P. Breast milk composition and infant nutrient intakes during the first 12 months of life. Eur. J. Clin. Nutr. 2016, 70, 250-256. [CrossRef] [PubMed]

3. Munblit, D.; Verhasselt, V.; Warner, J.O. Editorial: Human milk composition and health outcomes in children. Front. Pediatr. 2019, 7, 319. [CrossRef]

4. Miliku, K.; Duan, Q.L.; Moraes, T.J.; Becker, A.B.; Mandhane, P.J.; Turvey, S.E.; Lefebvre, D.L.; Sears, M.R.; Subbarao, P.; Field, C.J.; et al. Human milk fatty acid composition is associated with dietary, genetic, sociodemographic, and environmental factors in the CHILD Cohort Study. Am. J. Clin. Nutr. 2019, 110, 1370-1383. [CrossRef] [PubMed]

5. Gidrewicz, D.A.; Fenton, T.R. A systematic review and meta-analysis of the nutrient content of preterm and term breast milk. BMC Pediatr. 2014, 14, 216. [CrossRef]

6. Floris, L.M.; Stahl, B.; Abrahamse-Berkeveld, M.; Teller, I.C. Human milk fatty acid profile across lactational stages after term and preterm delivery: A pooled data analysis. Prostaglandins Leukot. Essent. Fat. Acids 2019, 102023. [CrossRef] [PubMed]

7. Boyce, C.; Watson, M.; Lazidis, G.; Reeve, S.; Dods, K.; Simmer, K.; McLeod, G. Preterm human milk composition: A systematic literature review. Br. J. Nutr. 2016, 116, 1033-1045. [CrossRef]

8. Lopez-Lopez, A.; Lopez-Sabater, M.C.; Campoy-Folgoso, C.; Rivero-Urgell, M.; Castellote-Bargallo, A.I. Fatty acid and sn-2 fatty acid composition in human milk from Granada (Spain) and in infant formulas. Eur. J. Clin. Nutr. 2002, 56, 1242-1254. [CrossRef]

9. Koletzko, B. Human Milk Lipids. Ann. Nutr. Metab. 2016, 69 (Suppl. 2), 28-40. [CrossRef]

10. Jensen, R.G. Lipids in human milk. Lipids 1999, 34, 1243-1271. [CrossRef]

11. Martin, C.R.; Ling, P.R.; Blackburn, G.L. Review of infant feeding: Key features of breast milk and infant formula. Nutrients 2016, 8, 279. [CrossRef]

12. Mozaffarian, D.; Ascherio, A.; Hu, F.B.; Stampfer, M.J.; Willett, W.C.; Siscovick, D.S.; Rimm, E.B. Interplay between different polyunsaturated fatty acids and risk of coronary heart disease in men. Circulation 2005, 111, 157-164. [CrossRef] [PubMed]

13. Aglago, E.K.; Huybrechts, I.; Murphy, N.; Casagrande, C.; Nicolas, G.; Pischon, T.; Fedirko, V.; Severi, G.; Boutron-Ruault, M.C.; Fournier, A.; et al. Consumption of fish and long-chain n-3 polyunsaturated fatty acids is associated with reduced risk of colorectal cancer in a large European cohort. Clin. Gastroenterol. Hepatol. 2019, 18, 654-666. [CrossRef] [PubMed]

14. Michalski, M.C.; Briard, V.; Michel, F.; Tasson, F.; Poulain, P. Size distribution of fat globules in human colostrum, breast milk, and infant formula. J. Dairy Sci. 2005, 88, 1927-1940. [CrossRef]

15. Zou, X.Q.; Guo, Z.; Huang, J.H.; Jin, Q.Z.; Cheong, L.Z.; Wang, X.G.; Xu, X.B. Human milk fat globules from different stages of lactation: A lipid composition analysis and microstructure characterization. J. Agric. Food Chem. 2012, 60, 7158-7167. [CrossRef] 
16. Bionaz, M.; Loor, J.J. Gene networks driving bovine milk fat synthesis during the lactation cycle. BMC Genom. 2008, 9, 366. [CrossRef]

17. Truchet, S.; Honvo-Houeto, E. Physiology of milk secretion. Best Pract. Res. Clin. Endocrinol. Metab. 2017, 31, 367-384. [CrossRef]

18. Mather, I.H. A review and proposed nomenclature for major proteins of the milk-fat globule membrane. J. Dairy Sci. 2000, 83, 203-247. [CrossRef]

19. Dewettinck, K.R.; Thienpont, N.; Thien Le, T.; Messens, K.; Van Camp, J. Nutritional and technological aspects of milk fat globule membrane material. Int. Dairy J. 2008, 18, 436-457. [CrossRef]

20. Chatterton, D.E.; Nguyen, D.N.; Bering, S.B.; Sangild, P.T. Anti-inflammatory mechanisms of bioactive milk proteins in the intestine of newborns. Int. J. Biochem. Cell. Biol. 2013, 45, 1730-1747. [CrossRef]

21. Bourlieu, C.D.; Deglaire, A.; De Oliveira, S.C.; Ménard, O.; Le Gouar, Y.; Carrière, F.; Dupont, D. Towards infant formula biomimetic of human milk structure and digestive behavior. Proceedings 2017, 24, 17. [CrossRef]

22. Bourlieu, C.; Menard, O.; De La Chevasnerie, A.; Sams, L.; Rousseau, F.; Madec, M.N.; Robert, B.; Deglaire, A.; Pezennec, S.; Bouhallab, S.; et al. The structure of infant formulas impacts their lipolysis, proteolysis and disintegration during in vitro gastric digestion. Food Chem. 2015, 182, 224-235. [CrossRef] [PubMed]

23. Wei, W.; Yang, J.; Yang, D.; Wang, X.; Yang, Z.; Jin, Q.; Wang, M.; Lai, J.; Wang, X. Phospholipid composition and fat globule structure i: Comparison of human milk fat from different gestational ages, lactation stages, and infant formulas. J. Agric. Food Chem. 2019, 67, 13922-13928. [CrossRef]

24. Gallier, S.; Vocking, K.; Post, J.A.; Van De Heijning, B.; Acton, D.; Van Der Beek, E.M.; Van Baalen, T. A novel infant milk formula concept: Mimicking the human milk fat globule structure. Colloids Surf. B Biointerfaces 2015, 136, 329-339. [CrossRef] [PubMed]

25. Moukarzel, S.; Dyer, R.A.; Garcia, C.; Wiedeman, A.M.; Boyce, G.; Weinberg, J.; Keller, B.O.; Elango, R.; Innis, S.M. Milk fat globule membrane supplementation in formula-fed rat pups improves reflex development and may alter brain lipid composition. Sci. Rep. 2018, 8, 15277. [CrossRef] [PubMed]

26. Ji, X.; Xu, W.; Cui, J.; Ma, Y.; Zhou, S. Goat and buffalo milk fat globule membranes exhibit better effects at inducing apoptosis and reduction the viability of HT-29 cells. Sci. Rep. 2019, 9, 2577. [CrossRef]

27. Hernell, O.; Domellof, M.; Grip, T.; Lonnerdal, B.; Timby, N. Physiological effects of feeding infants and young children formula supplemented with milk fat globule membranes. Nestle Nutr. Inst. Workshop Ser. 2019, 90, 35-42. [CrossRef]

28. Li, F.; Wu, S.S.; Berseth, C.L.; Harris, C.L.; Richards, J.D.; Wampler, J.L.; Zhuang, W.; Cleghorn, G.; Rudolph, C.D.; Liu, B.; et al. Improved Neurodevelopmental outcomes associated with bovine milk fat globule membrane and lactoferrin in infant formula: A randomized, controlled trial. J. Pediatr. 2019, 215, 24-31. [CrossRef]

29. Oosting, A.; van Vlies, N.; Kegler, D.; Schipper, L.; Abrahamse-Berkeveld, M.; Ringler, S.; Verkade, H.J.; van der Beek, E.M. Effect of dietary lipid structure in early postnatal life on mouse adipose tissue development and function in adulthood. Br. J. Nutr. 2014, 111, 215-226. [CrossRef]

30. Armand, M.; Hamosh, M.; Mehta, N.R.; Angelus, P.A.; Philpott, J.R.; Henderson, T.R.; Dwyer, N.K.; Lairon, D.; Hamosh, P. Effect of human milk or formula on gastric function and fat digestion in the premature infant. Pediatr. Res. 1996, 40, 429-437. [CrossRef]

31. Delplanque, B.; Gibson, R.; Koletzko, B.; Lapillonne, A.; Strandvik, B. Lipid quality in infant nutrition: Current knowledge and future opportunities. J. Pediatr. Gastroenterol. Nutr. 2015, 61, 8-17. [CrossRef]

32. Giuffrida, F.; Cruz-Hernandez, C.; Fluck, B.; Tavazzi, I.; Thakkar, S.K.; Destaillats, F.; Braun, M. Quantification of phospholipids classes in human milk. Lipids 2013, 48, 1051-1058. [CrossRef] [PubMed]

33. Tavazzi, I.; Fontannaz, P.; Lee, L.Y.; Giuffrida, F. Quantification of glycerophospholipids and sphingomyelin in human milk and infant formula by high performance liquid chromatography coupled with mass spectrometer detector. J. Chromatogr. B Anal. Technol. Biomed. Life Sci. 2018, 1072, 235-243. [CrossRef] [PubMed]

34. Dinkins, M.B.; Wang, G.; Bieberich, E. Sphingolipid-enriched extracellular vesicles and alzheimer's disease: A decade of research. J. Alzheimers Dis. 2017, 60, 757-768. [CrossRef] [PubMed]

35. Lopez, C.; Briard-Bion, V.; Menard, O.; Rousseau, F.; Pradel, P.; Besle, J.M. Phospholipid, sphingolipid, and fatty acid compositions of the milk fat globule membrane are modified by diet. J. Agric. Food Chem. 2008, 56, 5226-5236. [CrossRef] 
36. Moossavi, S.; Atakora, F.; Miliku, K.; Sepehri, S.; Robertson, B.; Duan, Q.L.; Becker, A.B.; Mandhane, P.J.; Turvey, S.E.; Moraes, T.J.; et al. Integrated analysis of human milk microbiota with oligosaccharides and fatty acids in the CHILD cohort. Front. Nutr. 2019, 6, 58. [CrossRef]

37. Walker, W.A.; Iyengar, R.S. Breast milk, microbiota, and intestinal immune homeostasis. Pediatr. Res. 2015, 77, 220-228. [CrossRef]

38. Leite, M.E.; Lasekan, J.; Baggs, G.; Ribeiro, T.; Menezes-Filho, J.; Pontes, M.; Druzian, J.; Barreto, D.L.; de Souza, C.O.; Mattos, A.; et al. Calcium and fat metabolic balance, and gastrointestinal tolerance in term infants fed milk-based formulas with and without palm olein and palm kernel oils: A randomized blinded crossover study. BMC Pediatr. 2013, 13, 215. [CrossRef]

39. Carnielli, V.P.; Luijendijk, I.H.; van Beek, R.H.; Boerma, G.J.; Degenhart, H.J.; Sauer, P.J. Effect of dietary triacylglycerol fatty acid positional distribution on plasma lipid classes and their fatty acid composition in preterm infants. Am. J. Clin. Nutr. 1995, 62, 776-781. [CrossRef]

40. Petit, V.; Sandoz, L.; Garcia-Rodenas, C.L. Importance of the regiospecific distribution of long-chain saturated fatty acids on gut comfort, fat and calcium absorption in infants. Prostaglandins Leukot. Essent. Fat. Acids 2017, 121, 40-51. [CrossRef]

41. Beghin, L.; Marchandise, X.; Lien, E.; Bricout, M.; Bernet, J.P.; Lienhardt, J.F.; Jeannerot, F.; Menet, V.; Requillart, J.C.; Marx, J.; et al. Growth, stool consistency and bone mineral content in healthy term infants fed sn-2-palmitate-enriched starter infant formula: A randomized, double-blind, multicentre clinical trial. Clin. Nutr. 2019, 38, 1023-1030. [CrossRef] [PubMed]

42. Miles, E.A.; Calder, P.C. The influence of the position of palmitate in infant formula triacylglycerols on health outcomes. Nutr. Res. 2017, 44, 1-8. [CrossRef] [PubMed]

43. Lu, P.; Bar-Yoseph, F.; Levi, L.; Lifshitz, Y.; Witte-Bouma, J.; de Bruijn, A.C.; Korteland-van Male, A.M.; van Goudoever, J.B.; Renes, I.B. High beta-palmitate fat controls the intestinal inflammatory response and limits intestinal damage in mucin Muc2 deficient mice. PLoS ONE 2013, 8, e65878. [CrossRef] [PubMed]

44. Jiang, T.; Liu, B.; Li, J.; Dong, X.; Lin, M.; Zhang, M.; Zhao, J.; Dai, Y.; Chen, L. Association between sn-2 fatty acid profiles of breast milk and development of the infant intestinal microbiome. Food Funct. 2018, 9 , 1028-1037. [CrossRef]

45. Bronsky, J.; Campoy, C.; Embleton, N.; Fewtrell, M.; Mis, N.F.; Gerasimidis, K.; Hojsak, I.; Hulst, J.; Indrio, F.; Lapillonne, A.; et al. Palm oil and beta-palmitate in infant formula: A position paper by the european society for paediatric gastroenterology, hepatology, and nutrition (ESPGHAN) committee on nutrition. J. Pediatr. Gastroenterol. Nutr. 2019, 68, 742-760. [CrossRef]

46. Zou, L.; Pande, G.; Akoh, C.C. Infant formula fat analogs and human milk fat: New focus on infant developmental needs. Annu. Rev. Food Sci. Technol. 2016, 7, 139-165. [CrossRef]

47. Sales-Campos, H.; Souza, P.R.; Peghini, B.C.; da Silva, J.S.; Cardoso, C.R. An overview of the modulatory effects of oleic acid in health and disease. Mini Rev. Med. Chem. 2013, 13, 201-210.

48. Cruz-Chamorro, L.; Puertollano, E.; de Cienfuegos, G.A.; Puertollano, M.A.; de Pablo, M.A. Acquired resistance to Listeria monocytogenes during a secondary infection in a murine model fed dietary lipids. Nutrition 2011, 27, 1053-1060. [CrossRef]

49. Cury-Boaventura, M.F.; Gorjao, R.; de Lima, T.M.; Newsholme, P.; Curi, R. Comparative toxicity of oleic and linoleic acid on human lymphocytes. Life Sci. 2006, 78, 1448-1456. [CrossRef]

50. Martin, C.R.; Dasilva, D.A.; Cluette-Brown, J.E.; Dimonda, C.; Hamill, A.; Bhutta, A.Q.; Coronel, E.; Wilschanski, M.; Stephens, A.J.; Driscoll, D.F.; et al. Decreased postnatal docosahexaenoic and arachidonic acid blood levels in premature infants are associated with neonatal morbidities. J. Pediatr. 2011, 159, 743-749.e2. [CrossRef]

51. Lofqvist, C.A.; Najm, S.; Hellgren, G.; Engstrom, E.; Savman, K.; Nilsson, A.K.; Andersson, M.X.; Hard, A.L.; Smith, L.E.H.; Hellstrom, A. Association of retinopathy of prematurity with low levels of arachidonic acid: A secondary analysis of a randomized clinical trial. JAMA Ophthalmol. 2018, 136, 271-277. [CrossRef]

52. Singh, P.; Ochoa-Allemant, P.; Brown, J.; Perides, G.; Freedman, S.D.; Martin, C.R. Effect of polyunsaturated fatty acids on postnatal ileum development using the fat- 1 transgenic mouse model. Pediatr. Res. 2019, 85, 556-565. [CrossRef] [PubMed] 
53. Najm, S.; Lofqvist, C.; Hellgren, G.; Engstrom, E.; Lundgren, P.; Hard, A.L.; Lapillonne, A.; Savman, K.; Nilsson, A.K.; Andersson, M.X.; et al. Effects of a lipid emulsion containing fish oil on polyunsaturated fatty acid profiles, growth and morbidities in extremely premature infants: A randomized controlled trial. Clin. Nutr. ESPEN 2017, 20, 17-23. [CrossRef] [PubMed]

54. Akinsulire, O.; Perides, G.; Anez-Bustillos, L.; Cluette-Brown, J.; Nedder, A.; Pollack, E.; Singh, P.; Liu, Y.; Sanchez-Fernandez, L.L.; Obregon, E.; et al. Early enteral administration of a complex lipid emulsion supplement prevents postnatal deficits in docosahexaenoic and arachidonic acids and increases tissue accretion of lipophilic nutrients in preterm piglets. JPEN J. Parenter. Enteral. Nutr. 2020, 44, 69-79. [CrossRef]

55. Vegge, A.; Thymann, T.; Lauritzen, L.; Bering, S.B.; Wiinberg, B.; Sangild, P.T. Parenteral lipids and partial enteral nutrition affect hepatic lipid composition but have limited short term effects on formula-induced necrotizing enterocolitis in preterm piglets. Clin. Nutr. 2015, 34, 219-228. [CrossRef]

56. Wang, X.; Liu, F.; Wang, Y.M.; Xue, C.H.; Tang, Q.J. The modulation effect of triglyceride type and phospholipids type $\omega-3$ LCPUFA on mice gut microbiota. J. Biosci. Med. 2017, 5, 11. [CrossRef]

57. Calder, P.C. Marine omega-3 fatty acids and inflammatory processes: Effects, mechanisms and clinical relevance. Biochim. Biophys. Acta 2015, 1851, 469-484. [CrossRef]

58. Marion-Letellier, R.; Savoye, G.; Beck, P.L.; Panaccione, R.; Ghosh, S. Polyunsaturated fatty acids in inflammatory bowel diseases: A reappraisal of effects and therapeutic approaches. Inflamm. Bowel Dis. 2013, 19, 650-661. [CrossRef]

59. John, S.; Luben, R.; Shrestha, S.S.; Welch, A.; Khaw, K.T.; Hart, A.R. Dietary n-3 polyunsaturated fatty acids and the aetiology of ulcerative colitis: A UK prospective cohort study. Eur. J. Gastroenterol. Hepatol. 2010, 22, 602-606. [CrossRef]

60. Barbosa, D.S.; Cecchini, R.; El Kadri, M.Z.; Rodriguez, M.A.; Burini, R.C.; Dichi, I. Decreased oxidative stress in patients with ulcerative colitis supplemented with fish oil omega-3 fatty acids. Nutrition 2003, 19, 837-842. [CrossRef]

61. Chan, S.S.; Luben, R.; Olsen, A.; Tjonneland, A.; Kaaks, R.; Lindgren, S.; Grip, O.; Bergmann, M.M.; Boeing, H.; Hallmans, G.; et al. Association between high dietary intake of the n-3 polyunsaturated fatty acid docosahexaenoic acid and reduced risk of Crohn's disease. Aliment. Pharmacol. Ther. 2014, 39, 834-842. [CrossRef] [PubMed]

62. Chan, S.S.; Hart, A.R. Commentary: The association between high dietary intake of docosahexaenoic acid and reduced risk of Crohn's disease-authors' reply. Aliment. Pharmacol. Ther. 2014, 39, 1332. [CrossRef] [PubMed]

63. Dichi, I.; Frenhane, P.; Dichi, J.B.; Correa, C.R.; Angeleli, A.Y.; Bicudo, M.H.; Rodrigues, M.A.; Victoria, C.R.; Burini, R.C. Comparison of omega-3 fatty acids and sulfasalazine in ulcerative colitis. Nutrition 2000, 16, 87-90. [CrossRef]

64. Lev-Tzion, R.; Griffiths, A.M.; Leder, O.; Turner, D. Omega 3 fatty acids (fish oil) for maintenance of remission in Crohn's disease. Cochrane Database Syst. Rev. 2014. [CrossRef]

65. Feagan, B.G.; Sandborn, W.J.; Mittmann, U.; Bar-Meir, S.; D’Haens, G.; Bradette, M.; Cohen, A.; Dallaire, C.; Ponich, T.P.; McDonald, J.W.; et al. Omega-3 free fatty acids for the maintenance of remission in Crohn disease: The EPIC randomized controlled trials. JAMA 2008, 299, 1690-1697. [CrossRef]

66. Lu, J.; Jilling, T.; Li, D.; Caplan, M.S. Polyunsaturated fatty acid supplementation alters proinflammatory gene expression and reduces the incidence of necrotizing enterocolitis in a neonatal rat model. Pediatr. Res. 2007, 61, 427-432. [CrossRef]

67. Wijendran, V.; Brenna, J.T.; Wang, D.H.; Zhu, W.; Meng, D.; Ganguli, K.; Kothapalli, K.S.; Requena, P.; Innis, S.; Walker, W.A. Long-chain polyunsaturated fatty acids attenuate the IL-1beta-induced proinflammatory response in human fetal intestinal epithelial cells. Pediatr. Res. 2015, 78, 626-633. [CrossRef]

68. Whiting, C.V.; Bland, P.W.; Tarlton, J.F. Dietary n-3 polyunsaturated fatty acids reduce disease and colonic proinflammatory cytokines in a mouse model of colitis. Inflamm. Bowel Dis. 2005, 11, 340-349. [CrossRef]

69. Usami, M.; Muraki, K.; Iwamoto, M.; Ohata, A.; Matsushita, E.; Miki, A. Effect of eicosapentaenoic acid (EPA) on tight junction permeability in intestinal monolayer cells. Clin. Nutr. 2001, 20, 351-359. [CrossRef]

70. Ferrer, R.; Moreno, J.J. Role of eicosanoids on intestinal epithelial homeostasis. Biochem. Pharmacol. 2010, 80, 431-438. [CrossRef]

71. Li, Q.; Zhang, Q.; Wang, M.; Zhao, S.; Xu, G.; Li, J. n-3 polyunsaturated fatty acids prevent disruption of epithelial barrier function induced by proinflammatory cytokines. Mol. Immunol. 2008, 45, 1356-1365. [CrossRef] 
72. Willemsen, L.E.; Koetsier, M.A.; Balvers, M.; Beermann, C.; Stahl, B.; van Tol, E.A. Polyunsaturated fatty acids support epithelial barrier integrity and reduce IL-4 mediated permeability in vitro. Eur. J. Nutr. 2008, 47, 183-191. [CrossRef] [PubMed]

73. Charpentier, C.; Chan, R.; Salameh, E.; Mbodji, K.; Ueno, A.; Coeffier, M.; Guerin, C.; Ghosh, S.; Savoye, G.; Marion-Letellier, R. Dietary n-3 PUFA may attenuate experimental colitis. Mediat. Inflamm. 2018, 2018, 8430614. [CrossRef] [PubMed]

74. Bento, A.F.; Claudino, R.F.; Dutra, R.C.; Marcon, R.; Calixto, J.B. Omega-3 fatty acid-derived mediators 17(R)-hydroxy docosahexaenoic acid, aspirin-triggered resolvin D1 and resolvin D2 prevent experimental colitis in mice. J. Immunol. 2011, 187, 1957-1969. [CrossRef] [PubMed]

75. Marcon, R.; Bento, A.F.; Dutra, R.C.; Bicca, M.A.; Leite, D.F.; Calixto, J.B. Maresin 1, a proresolving lipid mediator derived from omega-3 polyunsaturated fatty acids, exerts protective actions in murine models of colitis. J. Immunol. 2013, 191, 4288-4298. [CrossRef] [PubMed]

76. Cho, J.Y.; Chi, S.G.; Chun, H.S. Oral administration of docosahexaenoic acid attenuates colitis induced by dextran sulfate sodium in mice. Mol. Nutr. Food Res. 2011, 55, 239-246. [CrossRef]

77. Camuesco, D.; Comalada, M.; Concha, A.; Nieto, A.; Sierra, S.; Xaus, J.; Zarzuelo, A.; Galvez, J. Intestinal anti-inflammatory activity of combined quercitrin and dietary olive oil supplemented with fish oil, rich in EPA and DHA (n-3) polyunsaturated fatty acids, in rats with DSS-induced colitis. Clin. Nutr. 2006, 25, 466-476. [CrossRef] [PubMed]

78. Camuesco, D.; Galvez, J.; Nieto, A.; Comalada, M.; Rodriguez-Cabezas, M.E.; Concha, A.; Xaus, J.; Zarzuelo, A. Dietary olive oil supplemented with fish oil, rich in EPA and DHA (n-3) polyunsaturated fatty acids, attenuates colonic inflammation in rats with DSS-induced colitis. J. Nutr. 2005, 135, 687-694. [CrossRef]

79. Gobbetti, T.; Ducheix, S.; le Faouder, P.; Perez, T.; Riols, F.; Boue, J.; Bertrand-Michel, J.; Dubourdeau, M.; Guillou, H.; Perretti, M.; et al. Protective effects of n-6 fatty acids-enriched diet on intestinal ischaemia/reperfusion injury involve lipoxin A4 and its receptor. Br. J. Pharmacol. 2015, 172, 910-923. [CrossRef] [PubMed]

80. Dufton, N.; Perretti, M. Therapeutic anti-inflammatory potential of formyl-peptide receptor agonists. Pharmacol. Ther. 2010, 127, 175-188. [CrossRef]

81. Caplan, M.S.; Russell, T.; Xiao, Y.; Amer, M.; Kaup, S.; Jilling, T. Effect of polyunsaturated fatty acid (PUFA) supplementation on intestinal inflammation and necrotizing enterocolitis (NEC) in a neonatal rat model. Pediatr. Res. 2001, 49, 647-652. [CrossRef] [PubMed]

82. De Plaen, I.G.; Liu, S.X.; Tian, R.; Neequaye, I.; May, M.J.; Han, X.B.; Hsueh, W.; Jilling, T.; Lu, J.; Caplan, M.S. Inhibition of nuclear factor-kappaB ameliorates bowel injury and prolongs survival in a neonatal rat model of necrotizing enterocolitis. Pediatr. Res. 2007, 61, 716-721. [CrossRef]

83. Caplan, M.S.; Jilling, T. The role of polyunsaturated fatty acid supplementation in intestinal inflammation and neonatal necrotizing enterocolitis. Lipids 2001, 36, 1053-1057. [CrossRef] [PubMed]

84. Ohtsuka, Y.; Okada, K.; Yamakawa, Y.; Ikuse, T.; Baba, Y.; Inage, E.; Fujii, T.; Izumi, H.; Oshida, K.; Nagata, S.; et al. omega-3 fatty acids attenuate mucosal inflammation in premature rat pups. J. Pediatr. Surg. 2011, 46, 489-495. [CrossRef] [PubMed]

85. Akisu, M.; Baka, M.; Coker, I.; Kultursay, N.; Huseyinov, A. Effect of dietary n-3 fatty acids on hypoxia-induced necrotizing enterocolitis in young mice. n-3 fatty acids alter platelet-activating factor and leukotriene B4 production in the intestine. Biol. Neonate 1998, 74, 31-38. [CrossRef]

86. Smithers, L.G.; Gibson, R.A.; McPhee, A.; Makrides, M. Effect of long-chain polyunsaturated fatty acid supplementation of preterm infants on disease risk and neurodevelopment: A systematic review of randomized controlled trials. Am. J. Clin. Nutr. 2008, 87, 912-920. [CrossRef]

87. Fewtrell, M.S.; Abbott, R.A.; Kennedy, K.; Singhal, A.; Morley, R.; Caine, E.; Jamieson, C.; Cockburn, F.; Lucas, A. Randomized, double-blind trial of long-chain polyunsaturated fatty acid supplementation with fish oil and borage oil in preterm infants. J. Pediatr. 2004, 144, 471-479. [CrossRef]

88. Carlson, S.E.; Montalto, M.B.; Ponder, D.L.; Werkman, S.H.; Korones, S.B. Lower incidence of necrotizing enterocolitis in infants fed a preterm formula with egg phospholipids. Pediatr. Res. 1998, 44, 491-498. [CrossRef]

89. Zhang, P.; Lavoie, P.M.; Lacaze-Masmonteil, T.; Rhainds, M.; Marc, I. Omega-3 long-chain polyunsaturated fatty acids for extremely preterm infants: A systematic review. Pediatrics 2014, 134, 120-134. [CrossRef]

90. Fewtrell, M.S.; Morley, R.; Abbott, R.A.; Singhal, A.; Isaacs, E.B.; Stephenson, T.; MacFadyen, U.; Lucas, A. Double-blind, randomized trial of long-chain polyunsaturated fatty acid supplementation in formula fed to preterm infants. Pediatrics 2002, 110, 73-82. [CrossRef] 
91. Innis, S.M.; Adamkin, D.H.; Hall, R.T.; Kalhan, S.C.; Lair, C.; Lim, M.; Stevens, D.C.; Twist, P.F.; Diersen-Schade, D.A.; Harris, C.L.; et al. Docosahexaenoic acid and arachidonic acid enhance growth with no adverse effects in preterm infants fed formula. J. Pediatr. 2002, 140, 547-554. [CrossRef] [PubMed]

92. Clandinin, M.T.; Van Aerde, J.E.; Merkel, K.L.; Harris, C.L.; Springer, M.A.; Hansen, J.W.; Diersen-Schade, D.A. Growth and development of preterm infants fed infant formulas containing docosahexaenoic acid and arachidonic acid. J. Pediatr. 2005, 146, 461-468. [CrossRef] [PubMed]

93. Henriksen, C.; Haugholt, K.; Lindgren, M.; Aurvag, A.K.; Ronnestad, A.; Gronn, M.; Solberg, R.; Moen, A.; Nakstad, B.; Berge, R.K.; et al. Improved cognitive development among preterm infants attributable to early supplementation of human milk with docosahexaenoic acid and arachidonic acid. Pediatrics 2008, 121, 1137-1145. [CrossRef] [PubMed]

94. Makrides, M.; Gibson, R.A.; McPhee, A.J.; Collins, C.T.; Davis, P.G.; Doyle, L.W.; Simmer, K.; Colditz, P.B.; Morris, S.; Smithers, L.G.; et al. Neurodevelopmental outcomes of preterm infants fed high-dose docosahexaenoic acid: A randomized controlled trial. JAMA 2009, 301, 175-182. [CrossRef]

95. Collins, C.T.; Gibson, R.A.; Makrides, M.; McPhee, A.J.; Sullivan, T.R.; Davis, P.G.; Thio, M.; Simmer, K.; Rajadurai, V.S.; Team, N.R.I. The N3RO trial: A randomised controlled trial of docosahexaenoic acid to reduce bronchopulmonary dysplasia in preterm infants $<29$ weeks' gestation. BMC Pediatr. 2016, 16, 72. [CrossRef]

96. Collins, C.T.; Makrides, M.; McPhee, A.J.; Sullivan, T.R.; Davis, P.G.; Thio, M.; Simmer, K.; Rajadurai, V.S.; Travadi, J.; Berry, M.J.; et al. Docosahexaenoic acid and bronchopulmonary dysplasia in preterm infants. N. Engl. J. Med. 2017, 376, 1245-1255. [CrossRef]

97. Koning, N.; Kessen, S.F.; Van Der Voorn, J.P.; Appelmelk, B.J.; Jeurink, P.V.; Knippels, L.M.; Garssen, J.; Van Kooyk, Y. Human milk blocks DC-SIGN-pathogen interaction via MUC1. Front. Immunol. 2015, 6, 112. [CrossRef]

98. Yolken, R.H.; Peterson, J.A.; Vonderfecht, S.L.; Fouts, E.T.; Midthun, K.; Newburg, D.S. Human milk mucin inhibits rotavirus replication and prevents experimental gastroenteritis. J. Clin. Investig. 1992, 90, 1984-1991. [CrossRef]

99. Stevens, C.R.; Millar, T.M.; Clinch, J.G.; Kanczler, J.M.; Bodamyali, T.; Blake, D.R. Antibacterial properties of xanthine oxidase in human milk. Lancet 2000, 356, 829-830. [CrossRef]

100. Hanayama, R.; Tanaka, M.; Miwa, K.; Shinohara, A.; Iwamatsu, A.; Nagata, S. Identification of a factor that links apoptotic cells to phagocytes. Nature 2002, 417, 182-187. [CrossRef]

101. Miksa, M.; Wu, R.; Dong, W.; Das, P.; Yang, D.; Wang, P. Dendritic cell-derived exosomes containing milk fat globule epidermal growth factor-factor VIII attenuate proinflammatory responses in sepsis. Shock 2006, 25, 586-593. [CrossRef] [PubMed]

102. Cui, T.; Miksa, M.; Wu, R.; Komura, H.; Zhou, M.; Dong, W.; Wang, Z.; Higuchi, S.; Chaung, W.; Blau, S.A.; et al. Milk fat globule epidermal growth factor 8 attenuates acute lung injury in mice after intestinal ischemia and reperfusion. Am. J. Respir. Crit. Care Med. 2010, 181, 238-246. [CrossRef] [PubMed]

103. Matsuda, A.; Jacob, A.; Wu, R.; Zhou, M.; Nicastro, J.M.; Coppa, G.F.; Wang, P. Milk fat globule-EGF factor VIII in sepsis and ischemia-reperfusion injury. Mol. Med. 2011, 17, 126-133. [CrossRef]

104. Chogle, A.; Bu, H.F.; Wang, X.; Brown, J.B.; Chou, P.M.; Tan, X.D. Milk fat globule-EGF factor 8 is a critical protein for healing of dextran sodium sulfate-induced acute colitis in mice. Mol. Med. 2011, 17, 502-507. [CrossRef]

105. Bu, H.F.; Zuo, X.L.; Wang, X.; Ensslin, M.A.; Koti, V.; Hsueh, W.; Raymond, A.S.; Shur, B.D.; Tan, X.D. Milk fat globule-EGF factor 8/lactadherin plays a crucial role in maintenance and repair of murine intestinal epithelium. J. Clin. Investig. 2007, 117, 3673-3683. [CrossRef]

106. Ogg, S.L.; Weldon, A.K.; Dobbie, L.; Smith, A.J.; Mather, I.H. Expression of butyrophilin (Btn1a1) in lactating mammary gland is essential for the regulated secretion of milk-lipid droplets. Proc. Natl. Acad. Sci. USA 2004, 101, 10084-10089. [CrossRef]

107. Rhodes, D.A.; Reith, W.; Trowsdale, J. Regulation of Immunity by Butyrophilins. Annu. Rev. Immunol. 2016, 34, 151-172. [CrossRef]

108. Bhinder, G.; Allaire, J.M.; Garcia, C.; Lau, J.T.; Chan, J.M.; Ryz, N.R.; Bosman, E.S.; Graef, F.A.; Crowley, S.M.; Celiberto, L.S.; et al. Milk Fat globule membrane supplementation in formula modulates the neonatal gut microbiome and normalizes intestinal development. Sci. Rep. 2017, 7, 45274. [CrossRef]

109. Huang, S.; Wu, Z.; Liu, C.; Han, D.; Feng, C.; Wang, S.; Wang, J. Milk fat globule membrane supplementation promotes neonatal growth and alleviates inflammation in low-birth-weight mice treated with lipopolysaccharide. Biomed. Res. Int. 2019, 2019, 4876078. [CrossRef] 
110. Zhang, D.; Wen, J.; Zhou, J.; Cai, W.; Qian, L. Milk fat globule membrane ameliorates necrotizing enterocolitis in neonatal rats and suppresses lipopolysaccharide-induced inflammatory response in IEC-6 enterocytes. JPEN J. Parenter. Enteral. Nutr. 2019, 43, 863-873. [CrossRef]

111. Zavaleta, N.; Kvistgaard, A.S.; Graverholt, G.; Respicio, G.; Guija, H.; Valencia, N.; Lonnerdal, B. Efficacy of an MFGM-enriched complementary food in diarrhea, anemia, and micronutrient status in infants. J. Pediatr. Gastroenterol. Nutr. 2011, 53, 561-568. [CrossRef] [PubMed]

112. Miyake, H.; Lee, C.; Chusilp, S.; Bhalla, M.; Li, B.; Pitino, M.; Seo, S.; O'Connor, D.L.; Pierro, A. Human breast milk exosomes attenuate intestinal damage. Pediatr. Surg. Int. 2020, 36, 155-163. [CrossRef] [PubMed]

113. Gao, R.; Zhang, R.; Qian, T.; Peng, X.; He, W.; Zheng, S.; Cao, Y.; Pierro, A.; Shen, C. A comparison of exosomes derived from different periods breast milk on protecting against intestinal organoid injury. Pediatr. Surg. Int. 2019, 35, 1363-1368. [CrossRef] [PubMed]

114. Matei, A.C.; Antounians, L.; Zani, A. Extracellular Vesicles as a potential therapy for neonatal conditions: State of the art and challenges in clinical translation. Pharmaceutics 2019, 11, 404. [CrossRef] [PubMed]

115. Martin, C.; Patel, M.; Williams, S.; Arora, H.; Brawner, K.; Sims, B. Human breast milk-derived exosomes attenuate cell death in intestinal epithelial cells. Innate Immun. 2018, 24, 278-284. [CrossRef] [PubMed]

116. Wang, X.; Yan, X.; Zhang, L.; Cai, J.; Zhou, Y.; Liu, H.; Hu, Y.; Chen, W.; Xu, S.; Liu, P.; et al. Identification and peptidomic profiling of exosomes in preterm human milk: Insights into necrotizing enterocolitis prevention. Mol. Nutr. Food Res. 2019, 16, 1801247. [CrossRef]

117. Norris, G.H.; Milard, M.; Michalski, M.C.; Blesso, C.N. Protective properties of milk sphingomyelin against dysfunctional lipid metabolism, gut dysbiosis, and inflammation. J. Nutr. Biochem. 2019, 73, 108224. [CrossRef]

118. Nilsson, A. Role of sphingolipids in infant gut health and immunity. J. Pediatr. 2016, 173, S53-S59. [CrossRef]

119. Zhang, Y.; Cheng, Y.; Hansen, G.H.; Niels-Christiansen, L.L.; Koentgen, F.; Ohlsson, L.; Nilsson, A.; Duan, R.D. Crucial role of alkaline sphingomyelinase in sphingomyelin digestion: A study on enzyme knockout mice. J. Lipid Res. 2011, 52, 771-781. [CrossRef]

120. Nilsson, A. The presence of spingomyelin- and ceramide-cleaving enzymes in the small intestinal tract. Biochim. Biophys. Acta 1969, 176, 339-347. [CrossRef]

121. Wu, J.; Nilsson, A.; Jonsson, B.A.; Stenstad, H.; Agace, W.; Cheng, Y.; Duan, R.D. Intestinal alkaline sphingomyelinase hydrolyses and inactivates platelet-activating factor by a phospholipase C activity. Biochem. J. 2006, 394, 299-308. [CrossRef]

122. Andersson, D.; Kotarsky, K.; Wu, J.; Agace, W.; Duan, R.D. Expression of alkaline sphingomyelinase in yeast cells and anti-inflammatory effects of the expressed enzyme in a rat colitis model. Dig. Dis. Sci. 2009, 54, 1440-1448. [CrossRef]

123. Duan, R.D.; Cheng, Y.; Jonsson, B.A.; Ohlsson, L.; Herbst, A.; Hellstrom-Westas, L.; Nilsson, A. Human meconium contains significant amounts of alkaline sphingomyelinase, neutral ceramidase, and sphingolipid metabolites. Pediatr. Res. 2007, 61, 61-66. [CrossRef]

124. Norris, G.H.; Jiang, C.; Ryan, J.; Porter, C.M.; Blesso, C.N. Milk sphingomyelin improves lipid metabolism and alters gut microbiota in high fat diet-fed mice. J. Nutr. Biochem. 2016, 30, 93-101. [CrossRef]

125. Miklavcic, J.J.; Schnabl, K.L.; Mazurak, V.C.; Thomson, A.B.; Clandinin, M.T. Dietary ganglioside reduces proinflammatory signaling in the intestine. J. Nutr. Metab. 2012, 2012, 280286. [CrossRef]

126. Schnabl, K.L.; Larsen, B.; Van Aerde, J.E.; Lees, G.; Evans, M.; Belosevic, M.; Field, C.; Thomson, A.B.; Clandinin, M.T. Gangliosides protect bowel in an infant model of necrotizing enterocolitis by suppressing proinflammatory signals. J. Pediatr. Gastroenterol. Nutr. 2009, 49, 382-392. [CrossRef] [PubMed]

127. Park, E.J.; Suh, M.; Thomson, B.; Thomson, A.B.; Ramanujam, K.S.; Clandinin, M.T. Dietary ganglioside decreases cholesterol content, caveolin expression and inflammatory mediators in rat intestinal microdomains. Glycobiology 2005, 15, 935-942. [CrossRef] [PubMed]

128. Park, E.J.; Suh, M.; Thomson, B.; Ma, D.W.; Ramanujam, K.; Thomson, A.B.; Clandinin, M.T. Dietary ganglioside inhibits acute inflammatory signals in intestinal mucosa and blood induced by systemic inflammation of Escherichia coli lipopolysaccharide. Shock 2007, 28, 112-117. [CrossRef]

129. Rueda, R.; Sabatel, J.L.; Maldonado, J.; Molina-Font, J.A.; Gil, A. Addition of gangliosides to an adapted milk formula modifies levels of fecal Escherichia coli in preterm newborn infants. J. Pediatr. 1998, 133, 90-94. [CrossRef] 
130. Calder, P.C. Functional roles of fatty acids and their effects on human health. JPEN J. Parenter. Enteral. Nutr. 2015, 39, 18S-32S. [CrossRef]

131. Koletzko, B.; Bergmann, K.; Brenna, J.T.; Calder, P.C.; Campoy, C.; Clandinin, M.T.; Colombo, J.; Daly, M.; Decsi, T.; Demmelmair, H.; et al. Should formula for infants provide arachidonic acid along with DHA? A position paper of the European Academy of Paediatrics and the Child Health Foundation. Am. J Clin. Nutr. 2020, 111, 10-16. [CrossRef] article distributed under the terms and conditions of the Creative Commons Attribution (CC BY) license (http://creativecommons.org/licenses/by/4.0/). 